\title{
Hitliste: Ausgewählte Publikationen aus 20 Jahren MONICA/KORA Augsburg
}

Hit List: Selected Publications of 20 Years MONICA/KORA Augsburg

1 Peters A, von Klot S, Heier M, Trentinaglia I, Hörmann A, Wichmann HE et al. Exposure to Traffic and the Onset of Myocardial Infarction. N Engl J Med 2004; 351: $1721-1730$

2 Willich SN, Lewis M, Löwel H, Arntz HR, Schubert F, Schröder R. Physical exertion as a trigger of acute myocardial infarction. N Engl J Med 1993; 329: $1684-1690$

3 Schunkert H, Hense HW, Holmer SR, Stender M, Perz S, Keil U, Lorell BH, Riegger GAJ. Association between a deletion polymorphism of the angiotensin-converting-enzyme gene and left ventricular hypertrophy. N Engl J Med 1994; 330: 1634-1638

4 Siffert W, Rosskopf D, Siffert G, Busch S, Moritz A, Erbel R, Sharma AM, Ritz E, Wichmann HE, Jakobs KH, Horsthemke B. Association of a human G-protein B3 subunit variant with hypertension. Nat Genet 1998; 18: $45-48$

5 Koenig W, Sund M, Lowe GDO, Lee AJ, Resch KL, Tunstall-Pedoe H, Keil U, Ernst E. Geographical variations in plasma viscosity and relation to coronary event rates. Lancet 1994; 344: $711-714$

6 Peters A, Döring A, Koenig W. Increased plasma viscosity during an air pollution episode: a link to mortality? Lancet 1997; 349: 1582 - 1587

7 Geller F, Reichwald K, Dempfle A, Illig T, Vollmert C, Herpertz S, Siffert W, Platzer M, Hess C, Gudermann T, Biebermann H, Wichmann HE, Schäfer H, Hinney A, Hebebrand J. Melanocortin-4 receptor gene variant i103 is negatively associated with obesity. Am J Hum Gene 2004; 74 : $572-558$

8 Zhu X, McKenzie CA, Forrester T, Nickerson DA, Broeckel U, Schunkert H, Döring A, Jacob HJ, Cooper RS, Rieder MJ. Localization of a small genomic region associated with elevated ACE. Am J Hum Genet 2000; 67: 1144- 1153

9 Koenig W, Khuseyinova N, Löwel H, Trischler G, Meisinger C. Lipoprotein-associated phospholipase A2 adds to risk prediction of incident coronary events by C-reactive protein in apparently healthy middle-aged men with moderately elevated total cholesterol from the general population. Circulation 2004; 110: $1903-1908$

10 Koenig W, Löwel H, Baumert ], Meisinger C. C-reactive protein modulates risk prediction based on the Framingham Score. Implications for future risk assessment: Results from a large cohort study in southern Germany. Circulation 2004; 109: 1349-1353

11 Löwel H, Dobson A, Keil U, Herman B, Hobbs MST, Stewart A, Arstila M, Miettinen H, Mustaniemi H, Tuomilehto J. Coronary heart disease case fatality in four countries: A Community Study. Circulation 1993; 88: 2524-2531

12 Illig T, Bongardt F, Schöpfer A, Holle R, Müller S, Rathmann W, Meisinger C, Wichmann HE, Kolb H, KORA Study Group. The endotoxin receptor TLR 4 polymorphism is not associated with diabetes or components of the metabolic syndrome. Diabetes 2003; 52: 2861 - 2864

13 Meisinger C, Heier M, Döring A, Löwel H for the KORA group. Prevalence of known diabetes mellitus between 1984/85 and 1999/2001 in Southern Germany. Diabetes Care 2004; 27: 2985-2987

14 Thorand B, Löwel H, Schneider A, Kolb H, Meisinger C, Fröhlich M, Koenig W. C-Reactive Protein as a Predictor for Incident Diabetes Mellitus Among Middle-aged Men. Results From the MONICA Augsburg Cohort Study, 1984 - 1998. Arch Intern Med 2003; 163: 93 - 99

15 Meisinger C, Thorand B, Schneider A, Stieber J, Döring A, Löwel H. Sex Differences in Risk Factors for Incident Type 2 Diabetes Mellitus. Arch Intern Med 2002; 162: $82-89$

16 Weidinger S, Klopp N, Wagenpfeil S, Rümmler L, Schedel M, Kabesch M, Schäfer T, Darsow U, Jakob T, Behrendt H, Wichmann HE, Ring J, Illig T. Association of a STAT 6 haplotype with elevated serum IgE levels in a population based cohort of white adults. J Med Genet 2004, 41: 658-663

17 Meisinger C, Löwel H, Mraz W, König W. Prognostic value of apolipoprotein B and A-l in the prediction of myocardial infarction in middle-aged men and women: results from the MONICA/KORA Augsburg cohort study. Eur Heart J 2005; 26: 1-8

Hense $\mathrm{H}$, Schulte $\mathrm{H}$, Löwel H, Assmann G, Keil U. Framington risk function overestimates risk of coronary heart disease in men and women from Germany - Results from the MONICA Augsburg and the PROCAM cohorts. Eur Heart J 2003; 24: 937

19 Keil U, Liese AD, Hense HW, Filipiak B, Döring A, Stieber J, Löwel H. Classical risk factors and their impact on incident non-fatal and fatal myocardial 6,0 infarction and all-cause mortality in southern Germany. Results from the MONICA Augsburg cohort study 1984-1992. Eur Heart J 1998; 19 : $1197-1207$

20 Peters A, Fröhlich M, Döring A, Immervoll T, Wichmann H-E, Hutchinson LW, Pepys MB, Koenig W. Particulate air pollution is associated with an acute phase response in men. Eur Heart J 2001; 22: 1198-1204 